\title{
Some Theoretical and Practical Issues on the Impact of CSR on the Vietnam Textile and Garment Enterprises Operational Efficiency
}

\author{
Xuan Hung Nguyen* Hong Linh Nguyen Gia Linh Hua Phương Anh Le \\ Thi Minh Phuong Vu Mau Thanh Lam Nguyen \\ School of Trade and International Economics, National Economics University, 207 GiaiPhong, Hai Ba Trung, \\ Ha Noi, Vietnam
}

\begin{abstract}
The paper shows the impacts of corporate social responsibility (CSR) on the operational efficiency of Vietnamese textile enterprises by using primary data from qualitative analysis methods. The results show that corporate social responsibility has a great influence on the operational efficiency of textile enterprises in many ways. On that basis, the article proposes several recommendations for the Government of Vietnam as well as Vietnamese textile enterprises to well perform corporate social responsibilities.
\end{abstract}

Keywords:Corporate social responsibility (CSR), operational efficiency, financial performance

DOI: $10.7176 / \mathrm{EJBM} / 12-15-04$

Publication date:May $31^{\text {st }} 2020$

\section{Introduction}

Currently, the problems of accelerating economic growth are always associated with environmental, social, and community issues. Therefore, policies on social responsibility are formed. After the developed countries have been pioneering, the social responsibility activities are widespread in developing countries including Vietnam, especially in the trend of integration and fierce competition. Businesses play an important role in connecting stakeholders and pioneering global trends such as corporate social responsibility (CSR).

In terms of Vietnam, the textile and garment industry has been one of the key export industries for many years and gained encouraging results also created the value of exports and ensured consumer demand. Specifically, in the process of international economic integration, the signing of successful new-generation free trade agreements has created a great opportunity for Vietnam's textile and garment industry to penetrate new markets, develop new products and services, and fulfill the supply chain to meet the standards.

Therefore, the research team chose the topic of the effect of CSR on the operational efficiency of enterprises. The structure of the article includes:Introduction; Part 2 presents the research overview; Part 3 provides a theoretical basis for the impact of CSR on the performance of Vietnamese textile enterprises; Part 4 presents the methodology and research results; The last part is conclusions and some recommendations.

\section{Literature review}

According to Cameron (1986), the operational efficiency of an enterprise includes various aspects related to its operation without tension or internal error, besides, participating in legal activities, acquiring resources, and accomplishing the stated goals. Operational efficiency is a subset of organizational performance that includes performance and financial results.

Vance (1975) found a negative relationship between social responsibility and financial performance. In addition, Lopez et al. (2007) conducted a study to examine the entire business activity adversely affected by CSR. On the other hand, Kang et al. (2008) studied the different effects of positive and negative CSR activities on the financial performance of hotels, casinos, restaurants, and airlines. Hirigoyen and Poulain-Rehm (2015) point out the causal relationships between the various aspects of corporate social responsibility and financial performance. Chetty, Naidoo, Seetharam (2015) studied the impact of CSR on corporate financial performance.

The effect of social responsibility on performance is also through other factors of the business. Research of Brik et al. (2010) on market trends, corporate social responsibility and business performance. Obeidat (2016) aims to explore the relationship between corporate social responsibility, employee engagement and organizational performance in Jordan's mobile telecommunication businesses.

Previous studies mostly refer to CSR and financial performance more than other factors (production - business efficiency; social and environmental efficiency). However, financial performance is only an outcome or part of operational efficiency. Virtually, previous studies have not measured the impact of CSR on operational efficiency. Therefore, this is the research gap that the research team discovered and conducted. 


\section{Theoretical basis and background of the textile and garment industry}

\subsection{CSR Theory}

CSR has been defined in various ways since the 1960s, each one with its own meaning and approach. Most of the initial definitions of CSR focus on what constitutes corporate social responsibility; why businesses should be socially responsible (Fitch, 1976). Carroll (1979) argued that CSR was a combination of economic, legal, ethical, and social expectations for businesses. In 2010, Wood identified CSR so far as being extended to all three levels of responsibility: institutions and economy, business and organizations, and the individual level.

In order to the most general assessment of CSR, businesses should identify CSR from the theoretical perspective of stakeholders. Freeman et al. (2008) divided stakeholders into internal and external. The stakeholders inside the business are the people who are most important to the company's business operations, while outside are the stakeholders likely to influence perceptions and attitudes of internal stakeholders.

According to PhanThi Thu Hien (2019), CSR's benefits with enterprises are classified as monetary and nonmonetary benefits. Monetary benefits are direct benefits measured in monetary terms. Non-monetary benefits are not measured directly in monetary terms but still affect the competitiveness and financial efficiency of enterprises.

\subsection{The theory of the enterprise's operational efficiency \\ 3.2.1. Definition}

Operational efficiency can be understood in the most general sense of economic, political, social benefits that individuals or enterprises gain in their operation. It is possible to evaluate operational efficiency through the criteria of economic efficiency and social efficiency. However, the main criterion used is the financial efficiency of the business as every business has its first goal of maximizing profits.

\subsubsection{Evaluation criteria}

There are many criteria to evaluate operational efficiency; especially the selection of evaluation criteria is a key factor for the success of the enterprises. Therefore, the criteria for measuring the enterprise's operational efficiency are often divided into different groups, especially the financial indicators are the most common and often used in studies to assess the economic efficiency of enterprises: (1) Evaluation criteria based on production and business efficiency; (2) Evaluation criteria based on financial performance: are financial indicators; (3) Evaluation criteria are based on social and environmental efficiency.

\subsection{Background of Vietnam textile and garment industry}

Experiencing the history of formation and development with many changes, up to now, the textile and garment industry is holding an important position in Vietnam's economy in terms of growth rate and export expansion ability of the industry.

According to the Vietnam Textile and Apparel Association (VITAS) report on the performance of the textile and garment industry, by the end of 2019, the total export turnover of this sector reached 39 billion USD, decreasing 1 billion USD compared to the set target. Instead, the trade surplus reached the highest level ever with 17.7 billion USD. Compared to 1999, it increased by 22 times, from 17.5 billion USD to 39 billion USD.

The labor scale in the textile and garment industry is overwhelming. The industry has created about 2.2 million jobs every year. However, the labor force in textile and garment enterprises is mainly unskilled workers; the level of awareness, understanding of laws and international standards is still limited. It is not reason that textile enterprises do not guarantee workers' rights.

Although the textile and garment industry has increasingly improved with modern technologies, the environment is more severely affected. The waste from this industry is more harmful and unintended impact on ecosystems and citizens' lives. This is also a matter of concern for Vietnamese enterprises. Therefore, environmental protection policies and programs have also been implemented.

Furthermore, the textile and garment industry currently faces challenges as the current domestic raw material is in short supply because it is mainly imported from China and supply chain management, construction in Vietnam have not been allocated more resources to improving. However, the culmination is the trade war between the US and China. Previously, Vietnam's yarn exports to the US and China accounted for 3 billion USD and 2.4 billion USD respectively. Meanwhile, China has importedVietnam's yarn at a very low price; however, the export enterprises cannot sell. Because the US has imposed high taxes on textile products of China, China required Vietnam to reduce export prices, making textile enterprises in difficult situations

In conclusion, we have an overview of Vietnam's textile and garment industry, which is increasingly changing both in terms of quality and quantity. The production activities of the textile and garment industry interact with many stakeholders such as the environment, people, society, customers, etc., from which the effects of social responsibility will have impacts positively for the activities of Vietnamese textile enterprises. 


\section{Research methods and results}

\subsection{Research methods}

The main research method used is qualitative. The research team used, analyzed, compared primary data sources from previous scientific research, interviews with domestic and foreign experts, along with case studies on the impact of CSR on the effective performance of Vietnam National Textile and Garment Group (VINATEX). Through two phases: (i) Stage one: find an overview of CSR and the performance of the business; (ii) Stage two: learn about the impact of CSR on textile industry performance.

This study focuses on discovering new factors that are benefits that CSR brings in garment manufacturing and exporting enterprises. Sample data are referenced from typical CSR studies both at home and abroad, social science and social institutions, influencers, and the importance of compliance corporate social responsibility, social responsibility experts as well as officials responsible for corporate CSR policies in typical Vietnamese enterprises and textile enterprises, officials of Government departments or major organizations related to Vietnam's textile and apparel industry such as Vietnam Textile and Apparel Association (VITAS) and non-governmental organizations related to environmental protection and human rights.

\subsection{Research Results}

The research team made objective comments on the following issues: (i) Awareness on CSR of the Government, Enterprises in general and Textile enterprises in particular; (ii) The role of CSR; (iii) Impact of CSR on operational efficiency.

Awareness on CSR of the Government, Enterprises in general and Textile enterprises in particular

Since 2005, our State and Party have had policies and awards to honor enterprises that well-implemented CSR with the purpose of encouraging textile and garment enterprises to participate in sustainable development. It is noteworthy that in 2011, Vietnam implemented the first Socioeconomic Development Strategy from 2011 to 2020 with the view "Rapid development associated with sustainable development, sustainable development is strategy." The above results show that since the first year of accessing CSR, the Government of Vietnam always has highly appreciated and paid attention to this issue. However, there still needs to be clearer regulations and the development of business support programs in implementing CSR.neww

For exporting enterprises, especially in the period of FTA agreements, Pham Van Duc (2010) stated that corporate social responsibility has become one of the indispensable requirements for companies to access world markets. Research by Nguyen ThiNhan and Tran Thi Hang (2016) shows that currently, small and medium enterprises account for over $95 \%$ of total enterprises in Vietnam but are not interested in CSR implementation due to limited awareness and even distort the meaning of CSR of companies. In fact, many companies seriously violated state regulations on labor management, environmental protection, interests of consumers, and the community. Additionally, many enterprises violating the law on salaries, insurance regimes, and labor safety for employees are no longer a rare phenomenon, which has been pressing the society.

PhanThi Thu Hien (2019), points out the difference in perceptions of large and medium-sized enterprises through research on the frequency of conceptual occurrences in small and medium enterprises and large enterprises. The results also show that large enterprises carry out more comprehensive CSR activities and that brings many benefits to businesses.

In order to change and raise awareness of actions for the environment, VITAS has established an Environment Committee and has strongly participated in the action program "Greening the textile industry" with the coordination and support of many international organizations. The association has contributed to orienting businesses towards green production, sustainability, environmental protection, and taking it as an outstanding competitive criterion. In 2019, the "green" fashion policies and programs are increasingly emerging and receiving a lot of responses. The typical examples are the showcase of a collection called "Life in Motion" and the company's strategies for developing environmentally-friendly fabrics. In spite of small action, it contributes greatly to affirm the proper awareness of CSR as well as the sustainable development of the business.

The role of CSR

In addition to understanding enterprises' perceptions of corporate social responsibility, the research team offers benefits to enterprises in the general and garment and textile export enterprises in particular, to see motivations for enterprises to implement CSR. 
Table 4.1: Summary of the role of CSR from previous studies and expert judgment

\begin{tabular}{|c|c|c|}
\hline No. & Roles of CSR & Author, year \\
\hline 1 & Improving buying behavior & $\begin{array}{l}\text { Becker-Olsen et al. (2006); McDonald and Hung Lai } \\
\text { (2011); Le PhuocHuong and Luu Tien Thuan (2017) }\end{array}$ \\
\hline 2 & Getting more benefits in the short and long term & $\begin{array}{l}\text { Lee et al. (2012); Le PhuocHuong and Luu Tien } \\
\text { Thuan (2017) }\end{array}$ \\
\hline 3 & $\begin{array}{l}\text { Attracting more customers and retain existing } \\
\text { customers }\end{array}$ & Nguyen ThiNhan and Tran Thi Hang (2016) \\
\hline 4 & Increasing customer loyalty, increasing sales & $\begin{array}{l}\text { Crespo et al. (2005); Fatma and Rahman (2016); Le } \\
\text { PhuocHuong and Luu Tien Thuan (2017) }\end{array}$ \\
\hline 5 & Attracting talents for enterprises & Pham Van Duc (2010) \\
\hline 6 & $\begin{array}{l}\text { Improving the quality as well as the results of } \\
\text { the relationship between employees and } \\
\text { enterprises }\end{array}$ & $\begin{array}{l}\text { Lee et al. (2012); Le PhuocHuong and Luu Tien } \\
\text { Thuan (2017) }\end{array}$ \\
\hline 7 & $\begin{array}{l}\text { Evaluating international brands, gain public } \\
\text { trust through corporate policies. }\end{array}$ & Holt et al. (2004); Malik (2015) \\
\hline 8 & $\begin{array}{l}\text { Brand positioning tool for companies in } \\
\text { emerging markets }\end{array}$ & Karaosmanoglu et al. (2016) \\
\hline 9 & $\begin{array}{l}\text { Reducing costs, increasing productivity and } \\
\text { increasing revenue }\end{array}$ & Pham Van Duc (2010) \\
\hline 10 & $\begin{array}{l}\text { Priority is given to investors or banks to decide } \\
\text { whether to invest or lend to businesses }\end{array}$ & PhanThi Thu Hien (2019) \\
\hline
\end{tabular}

Source: Summary of the authors

In the current context, international economic integration is a common trend of the whole world and Vietnam is no exception as a member of the new generation FTA, the implementation of social responsibility is a challenge of garment and textile export enterprises in this period.

Mr. Thomas Mills (2018), the brand representative of Tommy Hilfiger, said that many Vietnamese textile enterprises need to change for sustainable development. Recently, the enew generation EVFTA Free Trade Agreement officially came into force, which not only benefits garment businesses such as tax reduction but also challenges and CSR is one of those factors. Vu DucGiang, Chairman of the Vietnam Textile and Apparel Association, affirmed, "If we do not change the production methods now, Vietnam will lose its competitiveness and opportunities." As such, CSR is a key to Vietnam in the process of international economic integration, and only when the requirements are met, Vietnamese textile enterprises will get benefits. In addition, stakeholders also have a profound influence on CSR implementation.

Impact of CSR on operational efficiency

The research team summarized the previous studies between CSR and financial performance in three results: negative, positive, and not statistically significant. 
Table 4.2: Summary of CSR relationship and financial performance from previous expert studies and findings

\begin{tabular}{|l|l|l|}
\hline No. & $\begin{array}{l}\text { Expert's studies } \\
\text { and findings }\end{array}$ & \multicolumn{1}{c|}{ Author, year } \\
\hline 1 & Negative & $\begin{array}{l}\text { Friedman (1970); Vance (1975), Wright and Ferris (1997); Wagner (2005), Lopez et } \\
\text { al. (2007); Hirigoyen and Poulain-Rehm (2015). }\end{array}$ \\
\hline 2 & Positive & $\begin{array}{l}\text { Freeman (1984); Brammer and Millington (2008); Lee and Park (2009); Mirsha and } \\
\text { Suar (2010); Tilakasiri (2012); Wu and Shen (2013); Rhou et al. (2016); Agyemang } \\
\text { and Ansong (2017) }\end{array}$ \\
\hline 3 & $\begin{array}{l}\text { Not statistically } \\
\text { significant }\end{array}$ & $\begin{array}{l}\text { Freedman and Jaggi (1982); Aupperle (1985); Teoh et al. (1999); McWilliams and } \\
\text { Siegel (2000); Kang et al. (2008); Makni et al. (2009); Aras et al. (2010); Pan et al. } \\
\text { (2014); Chetty, Naidoo and Seetharam (2015); Areola (2017) }\end{array}$ \\
\hline
\end{tabular}

Source: Compiled by the research team referencing the results of Le PhuocHuong and Luu Tien Thuan (2017)

From the perspective ofthe textile industry of Vietnam, the survey was conducted (2010) by the Institute of Labor Science and Social Affairs, which carried out on 24 enterprises of the Footwear industry and Textile industry. It showed that as the implementation of social responsibility of businesses, the revenue of these businesses has increased 25\%; labor productivity also rose from 34.2 million to 35.8 million/labor/ year and the rate of exports went up from $94 \%$ to $97 \%$.

For exporting enterprises, PhanThi Thu Hien (2019) stated: “The more exportsthe enterprises do, the better CSR programs the enterprises implement because CSR implementation can enhance their brand and prestige in the world market."

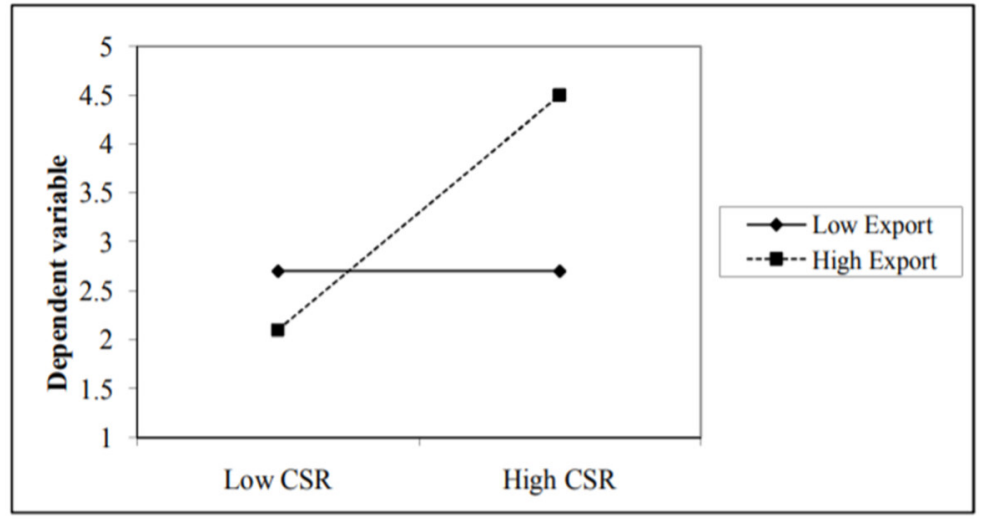

Figure 4.1: Regulatory role of the rate of export

Source: PhanThi Thu Hien, 2019

Moreover, in the study of PhanThi Thu Hien (2019), the author also assessed the CSR relationship according to 5 intermediate variables: Access to capital, Reputation, Staff satisfaction, Customer loyalty, Government support to financial efficiency. However, the results show that the relationship between CSR and financial performance is not sufficient to conclude that the relationship is intermediate. Therefore, the research team in this section will study the direct link between these two factors.

From the above-mentioned assessments, the relationship between corporate social responsibility and operational efficiencyin Vietnam's textile and garment industry, in particular, export textile enterprises may identify as positive trending.

\subsection{Case study of VINATEX}

\subsubsection{Introduction of VINATEX}

Vietnam National Textile Group and Garment Group (VINATEX) is a leading enterprise in the textile and apparel industry with the advantages of economic scale, wide distribution system, and complete production lines.

Vietnam National Textile and Garment Group is divided into 6 units of functional and advisory boards. The equipment used by VINATEX is mainly provided by famous manufacturers in the world with high automation, which helps to better control quality, increase productivity, and improve working conditions for workers.

Vietnam is currently in the process of international economic integration, VINATEX needs to have a strategy consistent with world regulations and CSR is one of those standards. VINATEX is leading in Vietnam's textile and apparel industry for the good implementation of this content. Therefore, the research team used VINATEX as 
evidence to see the impact of CSR on efficiency.

\subsubsection{Awareness about CSR of VINATEX}

VINATEX's vision - mission is associated with the motto of sustainable development including:

(1) To build value and customer satisfaction by turning Vietnam National Textile and Garment Group to be a premier textile and garment producer which can provide full package appeal solutions, fashionable, high quality and eco-friendly product to customers;

(2) To obtain an effective production system by continually improving management, developing skillful labor force, discovering innovative techniques, and delivering dynamic and professional working environment.

In order to deepen the vision - mission, the research team studied and synthesized activities related to CSR implementation of enterprises in VINATEX.

Table 4.3: Summary of enterprises in VINATEX with practical CSR actions

\begin{tabular}{|c|c|}
\hline Name & CSR practice \\
\hline $\begin{array}{c}\text { May } 10 \\
\text { Corporation }\end{array}$ & $\begin{array}{l}\text { To donate more than } 20 \text { billion VND to charity funds to implement social security } \\
\text { programs; to take care of } 24 \text { Vietnamese Heroic mothers; ... } \\
100 \% \text { of officials and employees are paid social insurance, health insurance, given gifts } \\
\text { on birthdays, weddings, standard helmets, visiting for help when facing difficulties ... }\end{array}$ \\
\hline $\begin{array}{l}\text { Hung Yen } \\
\text { Garment } \\
\text { Corporation }\end{array}$ & $\begin{array}{l}\text { To associate with Hanoi College of Textile - Garment and Fashion to open } 2 \text { training } \\
\text { courses to improve management skills for } 280 \text { team-level officials and send } 48 \text { officials to } \\
\text { attend training courses organized by Vietnam National Textile and Garment Group. } \\
\text { To actively participate in movements such as supporting funds with the amount of over } \\
\text { VND } 6.5 \text { billion, caring for } 2 \text { Vietnamese Heroic Mothers, ... }\end{array}$ \\
\hline $\begin{array}{l}\text { Dap } \\
\text { CauGarment } \\
\text { Corporation } \\
\text { joint-stock } \\
\text { company }\end{array}$ & $\begin{array}{l}\text { To create jobs for more than } 4,500 \text { employees, with an average income of } 8.7 \text { million } \\
\text { VND/person/month. } \\
\text { To fully implement the types of social insurance, health insurance, unemployment } \\
\text { insurance, and many other regimes as prescribed by the State. }\end{array}$ \\
\hline $\begin{array}{l}\text { Hue Textile } \\
\text { Garment Joint } \\
\text { Stock Company }\end{array}$ & $\begin{array}{l}\text { To invest in upgrading equipment at the Fiber Factory; To enhance production capacity to } \\
13,500 \text { tons of Ne } 30 \text { yarn/year; To replace old equipment, renovate and upgrade the } \\
\text { warehouse space. } \\
\text { To ensure regular employment for more than } 5,300 \text { thousand workers, with an average } \\
\text { income of } 6.52 \text { million VND/person/month. } \\
\text { To commend } 18 \text { collectives and } 45 \text { typical individuals in the movement of good labor and } \\
\text { creative labor with the amount of more than VND } 53 \text { million. }\end{array}$ \\
\hline $\begin{array}{l}\text { Viet Thang } \\
\text { Corporation }\end{array}$ & $\begin{array}{l}\text { To coordinate well with local authorities to volunteer activities such as: Participating in } \\
\text { the support programs for people with disabilities; Contributing to the program "gratitude } \\
\text { net for Hoang Sa, Truong Sa". } \\
\text { To improve conditions for employees to participate in social activities such as the Viet } \\
\text { Thang mini-football tournament, participating in Southern sports festival, ... }\end{array}$ \\
\hline
\end{tabular}

Source: Summary of the authors

The Group has participated in activities for the community, making an important contribution to social security. In the situation of Covid-19, VINATEX has officially launched a product line of translated masks with fiber material and special technology that strictly meets the guidelines of the Ministry of Health on the technical requirements of epidemic masks for use in the community; presenting antibacterial masks to Central Lung Hospital and Viet Xo Friendship Hospital, Central Eye Hospital, National Hospital of Pediatrics and Hanoi Medical University.

In terms of policies related to employees, especially, training policies, VINATEX has cooperated with 3 prestigious universities and training facilities to organize training courses, conferences, associations, specialized workshops to improve the professional capacity of officials with the number of more than 300 times/year.

Regarding environmental protection policy, VINATEX and its members have focused on sustainable development, so they always prioritize the implementation of environmental issues in the production process such as applying ISO 9001, ISO 14000. 
Table 4.4: Amount of wastewater used and cost of wastewater treatment of VINATEX in 2019

\begin{tabular}{|l|l|l|l|l|l|l|}
\hline $\begin{array}{l}\text { The amount of } \\
\text { wastewater in 2019 } \\
\left(\mathrm{m}^{3} / \text { year) }\right.\end{array}$ & $\begin{array}{l}\text { Compared to 2018 } \\
(\%)\end{array}$ & $\begin{array}{l}\text { Wastewater } \\
\text { treatment } \\
\text { technology }\end{array}$ & $\begin{array}{l}\text { Average costs of } \\
\text { Waste Management } \\
\text { Operations } \\
\text { (VND/m3) }\end{array}$ & $\begin{array}{l}\text { Wastewater } \\
\text { reuse rate (\%) }\end{array}$ \\
\hline $\begin{array}{l}\text { Industrial } \\
\text { water }\end{array}$ & Water & $\begin{array}{l}\text { Industrial } \\
\text { water }\end{array}$ & Water & & No \\
\hline 693,869 & 456,110 & $16 \%$ off & $\begin{array}{l}6 \% \\
\text { off }\end{array}$ & $\begin{array}{l}\text { Mainly using } \\
\text { Physical } \\
\text { Microbiology }\end{array}$ & 12.300 & \\
\hline
\end{tabular}

Source: VINATEX's annual report 2019

\subsubsection{Impact of CSR on VINATEX's operational efficiency}

By the above actions, it is said that VINATEX's operational efficiency has increased significantly. In 2020, VINATEX is stated that it always has played a key role in contributing to Vietnam's textile and garment industry. By 2019, export turnover reached over 39 billion USD, Vietnam Textile and Garment industry has ranked $3^{\text {rd }}$, confirming its position in the market. In 2019, the total revenue of the group reached nearly VND 20,139 billion, of which export turnover accounted for the majority of the total revenue. The US-China trade war since 2018 has negatively affected the yarn market, resulting in a $20-25 \%$ reduction in selling prices, affecting the Group's production and business efficiency. This proves that international customers like the US have a great influence on the operational efficiency of Vietnamese exporting enterprises.

For Europe and America markets, the implementation of CSR needs to be more stringent than ever because this is one of their extremely important standards. At the same time, CSR is one of the first requirements when negotiating to sign a contract, especially about the working environment, working conditions as well as incentives for employees.

In recent years, free trade agreements such as CPTPP and EVFTA have created a lot of opportunities for Vietnam's export industries, but this is also a big challenge because of the standards and especially the requirements of CSR are upheld. For the CPTPP, the agreement deals with labor issues in chapter 19 and the environment in chapter 20. Therefore, in order for Vietnam to receive tax incentives as well as improve export capabilities, and expand into new markets such as Canada and New Zealand, meeting the standards of export is required. Vietnam needs to change, raise its awareness, and confirm the role of CSR in influencing companies' operational efficiency. Thus, it is essential to change the way of implementation and ensure the rights of workers, communities, society, and the environment.

Currently, although VINATEX has the vision as well as specific actions to meet the standards of the international market, there is still a need for scrutiny to protect the rights of and its stakeholders.

\section{Conclusion and recommendations}

Through analysis and evaluation, this study has found evidence of the impact of CSR on the operational efficiency of Vietnam's textile and garment industry. The results also determine the importance of CSR in the field of sustainable development, especially in the integration period and raising awareness of Vietnamese textile enterprises. After studying, analyzing, and evaluating, the research team realized that there is a gap between the perception of large enterprises and both small and medium enterprises on this issue. While large enterprises place great importance on CSR implementation, small and medium enterprises are often concerned with immediate benefits and are constrained by their competence and expertise. Thus, many Vietnamese businesses have failed to fulfill their social responsibilities, which have led to actions that go against sustainable development, infringing on the interests of stakeholders.

Therefore, the textile industry needs a lot of effort to meet the requirements of the domestic and international community in recent years. In many cases, although enterprises are aware of the benefits and opportunities CSR can bring, they are still difficult to implement because ofbarriers. To assist Vietnamese textile and apparel enterprises in fulfilling their corporate social responsibility more effectively, especially overcoming challenging barriers, some recommendations are based on the proposed research results:

On the government side:Completing legal documents to enhance the implementation of corporate social responsibility; Proposing solutions to raise the awareness of corporate social responsibility; Strengthening inspection activities, effective inspection; Actively researching supporting mechanisms and policies for enterprises; Carrying out cooperation activities with international organizations, signing free trade agreements.

On the Vietnamese textile enterprise side: Raising awareness of corporate social responsibility; Establishing specialized research teams on CSR; Preserving and promoting the achieved achievements; Carrying out social 
responsibilities for environmental issues; Implementing social responsibilities to employees.

Textile enterprises in the world such as NIKE, ZARA, UNIQLO, etc. have achieved remarkable success in implementing social responsibilities. Vietnam's textile and apparel industry can learn from these brands to build up an appropriate strategy.

\section{REFERENCES}

Agyemang, O., Ansong, A. (2017). Corporate social responsibility and firm performance of Ghanaian SMEs: Mediating role of access to capital and firm reputation. Journal of Global Responsibility, 8(1), 47-62.

Cameron (1986). Effectiveness as Paradox: Consensus and Conflict in Conceptions of Organizational Effectiveness. Management Science, 32(5), 513-644.

Carroll (1979). A Three-Dimensional Conceptual Model of Corporate Performance.Academy of Management Review, 4(4).

Fombrun, C.J., Gardberg, N.A. and Barnett, M.L. (2000). Opportunity Platforms and Safety Nets: Corporate Citizenship and Reputational Risk. Business and Society Review, 105, 85-106.

Gérard Hirigoyen, Thierry Poulain-Rehm (2015). Relationships between Corporate Social Responsibility andFinancial Performance: What is the Causality?.Journal of Business \& Management, 4(1), 18-43.

Johnson, J.H., Farrell, W.C. Jr and Henderson, G.R. (1995). Mr Porter's 'competitive advantage' for inner-city revitalization: exploitation or empowerment?.Review of Black Political Economy, 24, 259-89.

Le, P.H. \&Luu, T.T. Corporate social responsibility - Summarizing some topics and proposing research directions.Journal of Science in Can Tho University,50, 19-33.

McWilliams, A. and Siegel, D. (1997). The role of money managers in assessing corporate social responsibility research. The Journal of Investing, 6 (4), 98-107.

Nguyen, T.N. \& Tran, T.H. (2016), Social responsibility (CSR) of small and medium enterprises. [Online] Available: http://kinhte.saodo.edu.vn/nghien-cuu-khoa-hoc/trach-nhiem-xa-hoi-csr-cua-doanh-nghiep-nhova-vua-320.html (April 20, 2020)

Pham, V.D. (2010), Corporate social responsibility in Vietnam: A number of urgent arguments and practices. [Online] Available: https://thongtinphapluatdansu.edu.vn/2010/02/20/4438/(February 20, 2010).

Pham, V.T. (2018). Corporate social responsibility (CSR) for employees in Vietnamese textile enterprises, Dissertation for MSc Economics, National Economics University.

Phan, T.T.H. (2019).Some issues of corporate social responsibility of Vietnamese textile enterprises. (1 ${ }^{\text {st }}$ d.).Labor - Social Publishing House. Hanoi.

Vance, S. (1975). Are Socially Responsible Corporations Good Investment Risks?.Managerial Review, 64, 18-24.

VINATEX, VINATEX's annual report 2019, Hanoi. 